\title{
Critical Theory in the Athropocene: Marcuse, Marxism and Ecology
}

This article aims to take up the challenge posed by the Anthropocene to Marxist social theory. Instead of engaging in some of the darker musings invited by the idea of the Anthropocene, I seek to argue that the 'environmental' crisis offers new possibilities to imagine possible futures. The point is not so much to become complicit with a future 'ecological desert, a sociological hell' but to think of historically based alternatives (Danowksi and de Castro 2017: 17). Responding to Andreas Malm's (2018: 220) argument that rather than indulge ourselves in dystopian fiction it is time to 'reroute utopian impulses'. Further if the 'richest 1 percent have a carbon foot-print some 175 times that of the poorest 10 percent' then climate change is about capitalism, class and justice (Malm 2018:189). The arrival of the Anthropocene asks us to rethink emancipatory movements and politics in a context where the global environment crisis threatens to undermine the secure foundation of human civilisation (Angus 2015, Bonneuil and Fressoz 2016, Klein 2018). The Anthropocene in effect raises the prospect of the end of human life on the planet (Bell 2011, Clark 2014). Timothy Luke (2017) warns that the panic surrounding the Anthropocene is increasingly giving legitimacy to a hierarchical project on behalf of technoscience seeking to manage 'nature' on behalf of humanity. Along with resigned pessimism this project erodes attempts by previous waves of critical theory to suggest new possibilities for humanity that could emerge through more radical environmental perspectives. In addition, and along with others, I want despite the recent cultural turn in social theory to maintain that a more realist sense of the natural world remains essential in terms of how we understand relations between humans and nature (Soper 1995, 2010, 2020,Williams 1980). A more materialist account should recognise the necessity of both a distinction between society and the nature, and suggest one of the central problems remains the dominance of the rule of private property. It is in the material interests of the dominant class to refuse to recognise ecological limits while perpetuating the endless extraction of fossil fuels in the pursuit of the accumulation of profit and economic growth.

Within the context of a social and historical crisis I seek to recapture some of the work of previous generations of critical theory especially that of Herbert Marcuse. Like many of the other radical ecological critics to emerge out of the radical 1960s 
including Bookchin (2004), Gorz (1982) Illich (1973), Williams (1980) and others, Marcuse (1964) was aware of the interconnections between a crisis in nature and society and that possibilities for a more emancipated society lie dormant within the present. However it was Marcuse's (1960:x) insistence on dialectical thought that was central to his approach exploring the contradictory nature of reality breaking the power of established and positivistic understandings of the world. For Marcuse (1964:120) reason offers the possibility of a 'transformation of negative into positive oppositions' thereby opening the possibility of other modernities. A global capitalist society built upon violence, exploitation and the destruction of nature is opposed by an equally global ecological and anti-capitalist movement demanding a different society. The point of dialectical thought being to both demonstrate the core contradictions at the heart of reality while at the same time refuting the reifying logic of a purely factual analysis (Marcuse 1960). The aesthetic realm and the natural world has a potententially liberatory dimension the extent to which they offer the possibility of more poetic understandings beyond mere instrumentality. In this sense, we also need to view reason itself as offering the possibility of free thought while at the same time observing the ways in which it can be drawn on help sustain a system of oppressive social relationships, deny our sensuous connection to nature and each other while erasing the power of estangement evident in modernist literature. Instead of resting within a reality built on the mental enslavement of capitalism, instrumentalism and violence, Marcuse sought to explore possibilities beyond so called scientific neutrality. Here I aim to demonstrate not only the on-going relevance of Marcuse and critical theory to Marxist debate, but that a dialectical analysis of the Anthropocene remains significant in the contxt of the twenty-first century.

\section{Marxism and Ecology}

If Marcuse remains important for his dialectical thinking and utopian sensibility he continues to offer an alternative to other Marxist approaches to ecology. John Bellamy Foster (2000) argues that the cultural turn in recent social theory has lost touch with an important component within Marx's thinking. Much environmental writing stands accused of rejecting the emancipatory possibilities opened up by science. Marx's materialism sought to join together a belief in an external physical reality and an investigation into the relational worlds imposed by capitalism. Marx 
continues to have a great deal to offer ecological thought through an analysis that is 'both materialist and dialectical' (Foster 2000:15). The problem with constructivist arguments is their tendency to deny the ontological separateness of nature. Under capitalism human-beings are both alienated from their labour, but also estranged from their bodies and wider ecological systems. These problems can-not be solved unless the rule of private property and the accumulation of profit are defeated bringing both the means of production and nature under more democratic forms of control. What matters is whether nature and broader social relations are dominated by estranged human-beings in the pursuit of profit or the recognition that human-beings both depend upon nature while at the same time being capable of transforming it in the interests of capital or the community. As Terry Eagleton (2016) suggests for Marx human-beings are not simply a material part of nature, but the agents capable of transforming themselves, nature and the urban environment. In this respect, we need to be careful about erasing the distinction between culture and nature as humanity has both a social and a natural history.

Similarly Kohei Saito (2017) has argued that some ecologically inspired critics have sought to dispense with Marx due to his presumed Prometheism, but in fact the 'mature' Marx is a valuable asset in helping us to understand the relations between political economy, history and nature. Saito (2017) is critical of a generation of Marxists from the 1960s who became overly concerned with the early Marx; instead what is significant is the separation of producers from their land, and the historical creation of a class of wage labourers. What an emphasis on the young Marx misses is his later critique of abstract philosophical categories in favour of the study of more material social relations. In addition Saito (2017:29) argues that the Marxist humanist writers of 1960s became explicitly focused on the early Marx as a means of wrestling Marxism away from Stalinism. The problem being that this has focused debate on ideas of 'species being' as opposed to the more concrete concerns of Marx's more materialist concerns with political economy.

A different but similarly Marxist approach is proposed by Neil Smith (1984/2008) who offers a more critical view of Marx given his failure to question the nature/culture divide. Missing from the Marxist cannon is the idea that capitalism is involved in 'the production of nature' (Smith 1984/2008:50). Here the argument is that nature and society can-not be finally separated and that regimes of capitalist accumulation alter the so called 'natural' world. Similarly James W. Moore (2015) 
argues historically throughout its formation and continuation that capital has historically depended upon the availability of cheap nature. Capitalism makes its profits through the web of life and this is likely to become more difficult in the future as costs rise. Within this view however Moore argues there is a need to move beyond the Cartesian view of the nature/society divide to look at how nature and capitalism produce one another. These features of course recall a specifically Marxist political economy that connects the ecological crisis to the deeply dysfunctional nature of modern capitalism (Streeck 2016). However Malm (2018:179) doubts that Moore's attempt to deconstruct the opposition between nature and society is an especially radical move. Moore is following theorists such as Bruno Latour (1993) and Steven Vogel (2015) in seeking to destablise this conceptual opposition (Malm 2018:182). For instance with Vogel (2015) such a position simply shifts attention from dialectical inter-relations between nature and society into one whereby the built environment becomes as 'natural' as the nature that surrounds it. As Foster (2016) argues we potentially lose a great deal once we erase the distinctions between capitalism and nature. Even within Moore's (2015) admittedly more critical account what becomes displaced is any sense that capitalism may indeed have 'natural' limits. Instead the emphasis shifts to capitalism's only internal contradictions produced through the rising cost of resources such as raw material etc (Foster 2016:405). The more 'realist' account of human and natural relations is in this respect more convincing.

Marcuse (1969) returns to the work of the young Marx not for the reasons outlined above but to recover a different idea of human emancipation beyond the concerns of a Marxism exclusively focused on structural relations. Marcuse (1968) argues that the society of 'democratic unfreedom' seeks to both increase people's standards of living while driving out critical thought. This is done by incorporating oppositional politics and art into the status quo while imposing a 'one-dimensional' view of reality. This cancels oppositional and dialectical modes of thinking by replacing movements for autonomy with hierarchically managed notions of the good society. The commodification of radical thought and the rule of technological rationality can be seen today in eco-consumerism and the idea that technology will fix the crisis evident within the relationship between human societies and the ecological system. The imposition of positivism and the 'happy consciousness' sought to cancel all 'negative' thought and deny the emancipatory possibilities that lay beyond the consumer society (Marcuse 1968). These concerns can-not be dismissed as outmoded 
as neoliberalism seems to rely on a happiness agenda geared to positive thinking and 'can do' optimism. This means that previously complex modes of thought and practice such as 'mindfulness'derived from Bhuddism become deployed as a means of social control (Purser 2019).

The return to the young Marx was an attempt to resurrect a more dialectical way of thinking opposed to consumerism's relentless need to be positive. What Marx was able to offer was a philosophy based on a poetic truth about the possibilities of humanity, but also a critique of false consciousness that contained the horizons of the working-class within the reified present. If capitalism colonises the imagination the socialism of the future would require a different sensibility that had 'developed an instinctual barrier against cruelty, brutality, ugliness' (Marcuse 1969: 21). Within this the early Marx offers a 'philosophy of praxis' that seeks to reimagine social theory beyond earlier problems of subject and object or fact and value (Feenberg 1981). It was Marx's dialectical materialism that argued that alienation was not a problem to be resolved within theory, but a practical problem requiring social transformation.

Especially significant is Marx's emphasis on the ways in which capitalism deforms the creative potential and capacities of humanity under conditions of alienation and subjugation. Under capitalism culture plays both an ideological role as well as a potentially liberating one given the human potential we all share for creativity and aesthetic forms of sensibility (Adams 1991). While the rule of private property makes us 'stupid' by insisting we focus on what we can own and possess this offers only a 'one-sided' understanding of our shared human capacities (Marx 1992:351). People 'burdened with worries and needs have no sense of the finest plays; the dealer in minerals sees only the commercial value, and not the beauty and peculiar nature of the minerals...etc' (Marx 1992:353). It is only 'the society that is fully developed that produces man in the richness of his being, the rich man who is profoundly and abundantly endowed with all his senses, as its constant reality' (Marx 1992:354). As we shall see, it is Marx's attention to the ways in which capitalism deforms the sensibilities of human-beings that allows Marcuse to develop his thought in ways that are missing from Saito and Foster. Marcuse's (1969) attempt to connect a Marxist ecological politics to a sensual, poetic and imaginative subject is a central aspect of his contribution. In this respect, Kate Soper (1996) argues that Marx remains valuable to ecological politics for his recognition that the world is ruled by the value of money rather than anything else, that commodity fetishism hides the ecologically destructive 
nature of the economic system, and that there exists a dialectical relationship between nature and humanity. Marx's early humanistic work emphasises the idea that under capitalism other values such as justice or aesthetic concerns were likely to be marginalised in a world driven by the demand for profit and commodity production. We now need to explore Marcuse's work in greater depth to see how he builds upon these critical insights.

\section{Marcuse, Nature and Liberation}

Marcuse's dependence on Hegel offers a distinctively different view to other Marxist approaches to nature and society. If his early intellectual formation was influenced by Heidegger then it was the failure of the 1918-19 German revolution that was to offer a different path. Valuing the demand for authenticity, Marcuse saw that Heidegger paid too little attention to concrete social and historical conditions (Wolin 2001). Perhaps even more revealing however was Marcuse's later recognition that despite concerns with alientation and authenticity, Heidegger's philosophy had little concern with love and more sensuous human relationships (Castro 2018: 40). Indeed it is only after Kant, through Hegel, that philosophy begins to question the rule of private property and the on-going social relations of domination and control (Marcuse 1972). Social theory needed to overcome the bourgeois tendency to focus on inner spiritual freedom abstracted from social relations before it could begin to question the dominance of private property. Within this Marcuse had long been critical of Lenninst-Marxism and rejected the idea that working-class required strict control by a trained group of revolutionaries. If under capitalism the bourgeoisie represents itself as representing the general interest then under more authoritarian versions of socialism an elite group does the same. Freedom therefore would require the socialisation of the means of production run in the interests of the community as a whole not a ruling elite.

The other aspect of bourgeois philosophy attacked by Marcuse (1968a) was the attempt to define humanity in its 'essence'. This was not only totalitarian, but equally depended upon the presumption the production of unmediated 'essential truths'. It was again Hegel who was significant in suggesting that 'essence has a history' (Marcuse 1968a:67). In other words, Hegel works with 'the tension between what could be and what exists, between the being-in-itself (essence) and appearance, into the very structure of Being' (Marcuse 1968a:69). These philosophical features 
move the problem from a definitive concern with essence into the search for the dialectical possibilities of human-beings, technology and nature. The realisation of these possibilities is of course far from inevitable and connects the organisation of labour, productive forces and the historical development of needs. Given the role of praxis in this state of affairs there will of course be human and other potentials that fail to become realised. It is the task of critical theory to both develop an economic rather than a purely philosophical theory of society that suggests human happiness is less a matter of 'inner freedom' than it is connected to the transformation of social relations (Marcuse 1968b).

Herbert Marcuse (1967) discovers within the early Marx a philosophy that went beyond the argument that altering the material relations of production would automatically lead to a more emancipated society. In Marcuse's reading of Marx what matters is not only capital's structural power over labour, but the implications this relationship had for self-fulfillment. In this respect, engaging in wage labour the worker 'mortifies his body and ruins his mind' (Marcuse 1967:277). Further that the worker's relationship to the world becomes reduced to a possessive, egoistic and acquisitive being. Marcuse (1967) like Marx suggests this opens up dialectical possibilities given the possibility of different kinds of human development that lie dormant within the present. For Marcuse (1967:283) after all it is 'free individuals, and not a new system of production, that exemplify the fact that the particular and the common interest have merged'. Missing from an approach that simply emphasises material relations from a Marcusian (2017a:343) perspective is the recognition that the civilisational shift required by socialism implies 'a different type of human-being with new needs, capable of finding a qualitatively different way of life, and of constructing a qualitatively different evironment'. Marcuse argues that it is wrong to pretend that a socialist society would create the same levels of material wealth and luxury as capitalism. Beyond the consumer society a different kind of human-being could emerge unwilling to tolerate the levels of pollution, destruction and sheer ugliness of capitalism.

The exploitation of nature by capitalism both prevents human-beings from seeing themselves as part of nature and disables the prospect of nature being recognised as 'a subject in its own right' (Marcuse 1972:60). An emancipated society would mutually liberate human-beings and the natural world recovering 'the lifeenhancing forces in nature, the sensuous aesthetic qualities which are foreign to a life 
wasted in unending competitive performances' (Marcuse 1972:60). The sensuous recovery of a less brutalised human being (also evident within the feminist movement) required a deeper relationship to the aesthetic and a society that had moved beyond instrumentalism and productivism (Marcuse 1972: 74). The domination of capitalism and commodity production both obscures the recognition that humanity is both part of and dependent upon nature and that the natural world should be recognised as a subject. If under the domination of capitalism and state socialism nature was simply raw material to be exploited there are new possibilities for humanity that could be opened up through the development of different kinds of social and ecological relationships and new human capacities. Marcuse's Marxism opens up questions as to whether or not a non-violent and less destructive relationship with the eco-system is possible. This would inevitably require 'a qualitatively different society' based upon the rejection of more masculinist, instrumental and productivist modes of domination (Marcuse 1972:74). In Marcuse's terms this implies not only a revolt against consumerism, the development of more aesthetic human capacities beyond those required by capitalism, but also a much deeper alliance with the feminist movement than had previously been anticipated by socialists in seeking to transform capitalism. Here Marcuse recognises that a different relationship to ecology is not simply a matter of democratic control, but would also involve the recovery of a feminised society. These features are suggestive of interconnections that might be sought between Marxism and eco-feminist modes of analysis (Kelly 1984, 1994, Merchant 1996). Herbert Marcuse (2019) to this end recognised that the women's liberation movement in the 1960s and 1970s were critical the extent to which they recognised the dehumanised nature of the dominant masculinity. Under capitalism women became 'idealised' as mothers and exploited as sexualised objects in the culture industry. Despite this women were often representative of a less barborous humanity given their on-going connecton to the values of care, sensuousness and tenderness. As we shall see, in the next section, like much ecofeminist writing, Marcuse sought to recover a culture of love and the erotic that he saw as central to the construction of an alternative and less repressive civilisation. 


\section{Freud, Marcuse and Fromm}

Marcuse explored many of these questions through an engagement with the work of Freud. Like Marx, Freud's writing was key in that it contained both critical and dialectical possibilities that pointed towards a less neurotic and more emancipated society. For Marcuse just as with Marx our troubles are rooted in the structure of society and our sense of alienation (or feeling sick) is a matter of the world in which we live (Marcuse 1968b:148). Marcuse (1987) offers a radical interpretation of Freud by subverting the more conservative implications of his theory by introducing the idea of surplus repression. He does this by radically reinterpreting the necessarily developmental conversion of the pleasure principle into a reality principle (the ability to form a realistic judgement about the outside world) in historical terms. If the inevitable triumph over the pleasure principle is historically and socially contingent; Marcuse reasons this opens the historical possibility of a non-repressive or at least less repressive civilisation (Marcuse 1987). If eros and the death instinct are the two most important biological drives then this is not simply a matter for the individual but concerns the organisation of the wider society. Capitalism is unable to realise the technological capacity to construct a society based on freedom due to the social relations of production; here the reality principle takes on an overly repressive form. Key here also was the dominance of what Marcuse (1987) identified as the governing performance principle of capitalism (and male dominance) that subordinated and instrumentalised the laboring and sexual body. Under capitalism progress had come to mean the destruction of life through war, ecological devastation, waste, spiritually empty consumption, and the tedious nature of waged labour. These aspects of modern life can all be connected to libidinous repression and are a central cause of human suffering. An emancipated civilisation should be judged by its ability to enable people to enjoy activities and pursuits as ends in themselves without the requirement that they be socially useful. Marcuse (1987:156) recognises that under what passes for civilisation '[e]fficency and repression converge: raising the productivity of labour is the sacrosanct ideal of both capitalism and Stalinist Stakhovism'. A new reality principle therefore is not simply a matter of changing social relations, but instead the creation of the 'release of time and energy for the free play of the human faculties' (Marcuse 1987:156). Beyond Promethous lies the possibility of a 'fuller Eros' that can find expression within sexuality, aesthetic creativity and everyday social 
relationships (Marcuse 1987:171). This would be a realm where the aesthetic, the sensuousness of the body and our capacity to reason would become reconciled with one another. The post-capitalist organisation of society would allow fuller expression to these aspects given that technology would be allowed to satisfy our shared needs leaving its members free to devote themselves to more more fufilling pursuits.

Many of these arguments were challenged at the time by Erich Fromm. While the precise nature of this dispute lies outside of our concerns Fromm (1971) makes some incisive points concerning Marcuse's misreading of Freud. If Fromm (1971:31) shares Marcuse's critique of ego psychology and positive thinking he argues the idea of the non-repressive society is 'an infantile paradise'. Within Marcuse's utopia Fromm detects a refusal to grow up and become a mature adult which is the opposite of Marx's vision of people able to love and become productive within the community. In addition, Fromm (1971) doubts the twentieth century is based on sexual repression as the consumer society is built on the demand for instant pleasure. The dominant marketing character is not based on libidenial denial, but the refusal to explore the authentic core of identity. Fromm (1976) later develops these arguments in identifying an opposition between 'having' and 'being'. If 'having' can be linked to the desire to control and possess then 'being' offers a more authentic way to our humanity through the desire to become related to others and the natural world. In short, being mode is less fixated on wealth, status and consumerism, but more concerned to develop the properties of a loving and relational human being. The other side of 'having' could be seen in the intense fear of death and losing status as without 'things' what am I? Instead of fitting ourselves into the machine of capitalism, Fromm advocates a decentralised vision of socialism not hierarchical control from above or the manipulation by the culture industry. If Fromm's and Marcuse's visions are not so far apart the crucial difference lies less in a vision for a different society, but in ideas of repression versus a focus on the ability of human's to develop their ability to fully experience themselves and the other. Historian of the Frankfurt school Martin Jay (2020:61) has mostly sided with Marcuse accusing Fromm of relying on 'spiritualised values' as opposed to a radical transformation of society. While the dispute may have led to Fromm's marginalisation from the Frankfurt school this does not mean he was wrong.

Fromm (1982) developed a reading of Freud that sought to draw out the possessive and bougeios nature of love that lies at the heart of his theory. Freud (and 
by implication Marcuse) do not explore in enough detail how the character structure of possessive individualism is culturally mediated. In this Freud fails to recognise that most of his patients simply aim to suffer less than become more human and potentially more critical in orientation. Fromm's (1982) position was that despite the crippling effects of the wider society and culture it was still possible with a considerable amount of personal effort to become a decent caring, responsible and relational person. This was made more difficult if not impossible by the empty values, narcissism and hierarchical nature of contemporary society.

Fromm's emphasis on the limited nature of the 'repression' model seems correct. Later Christopher Lasch (1980) would take these arguments further suggesting that capitalist modernity is less haunted by surplus repression but by a form of narcissism full of cravings and the lust for excitement instilled by the consumer society. The dominant personality type is no longer Freud's neurotic patients, but someone afraid of deep attachments and commitments who tends towards self-absorption while craving the approval of those in authority. Yet both Marcuse and Fromm are concerned that a lack of love for one another and for the world more generally is at the root of many of the globes problems. From war, economic exploitation to the violence turned against nature all demonstrate the destructive tendencies of human-beings and the wider society. Later Marcuse (2019) maintained his interest in Freud connecting the ecologically destructive nature of humanity evident within capitalism to the predominance of the death drive. It was only through the emergence of different subjectivities or a 'revolt of the life instincts against organised and and socialised destruction' that might offer hope to humanity. Again if I do not wish to defend Marcuse's investment in Freudian drive theory he similarly to Fromm suggests that radical change is dependent on the development of a 'non-conformist consciousness' (Marcuse 2019:13). It is not that Fromm (1994) discounted the conflict between Eros and Thantos, but hos work locates their expression in more cultural/biological terms connected to different ways of relating to the world. If life meant the capacity to change and grow, then death is expressed within a repetitive fear of challenge and difficulty. The problem was that the dominant consumer society required people who were both conformist (that they followed orders in a hierarchy) and saw the point of living as instant gratification. For Fromm (1964:8) the 'world has become one great big maternal breast, and man has become the eternal suckling, forever expectant, forever disappointed'. Our world creates a half 
awake person afraid to use their own reason, think their own thoughts and who spends the great majority of their lives on the hedonic treadmill. Fromm (1976:173) suggests a new society and hope for humanity would need to be built upon the 'strong potential within human nature'. While this is differently conceived to Marcuse, it will be the ability of humanity to revolt against the manipulative quality of bureaucratic reason and the marketing mentality that offers the best hope for survival for the species.

This returns us again to an appreciation of both Fromm (1976) and Marcuse's (2019c) arguments in terms of the destructive nature of a patriarchal society. Jessica Benjamin (1990) suggests the idea of the separateness of the bourgeous self and masculinished individual that was critiqued by Marcuse and Fromm lies at the base of much male domination. The devaluation of feminity and human capacities to love and relate to one another forming the basis of the dominant masculinity. In this respect, both Marcuse and Fromm were deeply concerned about a destructive and 'sick society' that valued conformity and market based-individualism over the capacity to lovingly relate to others. This was evident to Marcuse (1968c:259) in the context of the war in Vietnam where the aggressiveness of mainstream society was painfully evident within the 'brutalization of language and image, the presentation of killing, burning, and poisoning and torture inflicted upon the victims of neocolonial torture made in a common-sensible, factual, sometimes humorous style'. Fromm (1993) was similarly concerned about human destruction and the inter-play between Eros and Thantos and the manipulative aspects of capitalism encouraging people to adopt a conformist persona. Our salvation lies less within the removal of internal contraints but for a society more geared towards 'being' than 'having'. The desire to own, control and possess produces a society of cold and unfeeling people. Within this people demanded security (largely through what they could own) rather than risk and freedom. These aspects facilitated by living in a capitalist society tend to produce narcissitic people. Treating the self as a form of property, Fromm (1993:117) writes that 'the narcisstic person has built an invisible wall around himself. He is everything the world is nothing. Or rather: He is the world'. The root to a more 'adventorous' self implies giving up a concern with property and status, and becoming increasing interested in and related to the worlds of nature and society.

What Marcuse (1972b) and Fromm (1971) introduce into the argument is the need for a more complex understanding of subjectivity beyond questions of economic domination. Eco-socialism and Marxist humanism has a long history of opposing the 
destructive nature of capitalism to more humanistic concerns. The class power of the global one per cent is negatively contrasted to the possibility of creating a more ecologically sustainable and humane social order. Indeed if the Anthropocene can be traced back to the industrial revolution then we need to recognise that it has mostly taken off with the advent of the consumer society in the 1950s and 1960s. The devastating impacts of climate change move us into a new era and ecologically and with the price most likely to be paid in the short term at least by the poor of the planet. Such features not only open the need for 'drastic emission reductions', but also strongly suggest that consumer orientated capitalist societies show no signs of being able to satisfy the need for a more just and sustainable world (Angus 2016:194). Such questions inevitably raise questions of the possibilities of transformation, and of course the kinds of identities and subjectivities that hold the system together. Marcuse (1978) indicates that sometimes missing from this paradigm is an appreciation of the different human sensibilities that are required to begin such a transition. Similarly Joel Kovel (2008:8) argues that eco-socialism needs to move the conversation away from only talking about human welfare to thinking about the inter-relationship between humanity and eco-systems. This new sensibility remains humanist the extent to which is rejects the idea of the equal value of all life-forms, but also needs a sense of wonder in relation to the natural world. These arguments introduce concerns about how alternative moralities and sensibilities become rooted within the life of the community more generally. Kovel (2002:79) goes on that new ecological sensibilities are required to counteract feelings of grandiosity and the cold hearted sense of calculation that is deliberately fostered by a world of corporate power. The blatantly egotistical features of capitalism are not especially compatible with the more reciprocal, caring and less dominating attributes needed by an ethical and ecological society. All of the features are of course at least partially prefigured by some of Marcuse's and Fromm's reflections.

Andrew Feenburg (2005:112) argues that in this respect Marcuse offers what we might call a 'civilisation politics' as opposed to a politics that is mainly concerned with how to mobilise social forces to capture power or identity politics. Instead of in Marcuse's (2001a:116) terms of going on with the 'rat race' we 'devote our resources to the elimination of the material and spiritual garbage with which established societies are covered not figuratively but literally, our mental and physical spaces, and to construct a peaceful and beautiful universe'. Such a transformation would require a 
cultural revolution whereby humanity develops new and less exploitative relationships (where instrumentality is minimised without being entirely banished) finding a new place for human capacities such as love, co-operation and friendship (Marcuse 2001b). These features necessarily point to a more utopian eco-socialist politics away more immediate considerations (Kellner 1984:323). In other words, the ability to imagine poetic alternatives remains an essential attribute of more contemporary social movements.

\section{A Humane Politics of Hope}

An eco-socialist ethics and politics is a search for a way of life beyond that determined by aggressive capitalism and the authoritarian politics of the state. Such a politics is poorly served by neoliberalism and a politics of enclosure where public assets and nature are threatened by a predatory politics of privatisation (Boal et al 2005). In this setting, a new radical politics developed by the alter-globalisation movement has been concerned with the struggle over the commons (Pleyers 2010, Stevenson 2017). This has been more recently ignited by the emergence of a number of more radical environmental movements, the widespread participation of young people in the global climate strikes of 2019 and the global celebrity of Greta Thunberg. Within global justice movements and ecological campaigns there is the beginning of the emergence of a sensibility that is being to question an anthropocentrism which priorities the rights of humans and 'development' more generally to simply make 'use' nature and other species. If nature is a commons it is not simply a resource to be used by the economic system. Wolfgang Sachs (2017:2581) suggests the development of global eco-solidarities could begin to question 'the imperial lifestyle of the transnational middle classes', authoritarian politics and ethnic nationalism. Notably as with the radical 1960s the arrival of a new ethical politics has mainly taken root amongst young civic actors. There is within these movements an engagement with alternative utopia's that search for a world beyond 'business as usual'. Marcuse (1964) would have recognised the dialectical as well as the democratic potential of these movements to prioritise critical values and judgements as well as the argument that life on earth could and should be made better for everyone. As Marcuse would have maintained the recovery of more utopian sensibilities is required to help imagine other possibilities and consider how they 
might become connected to a more hopeful politics. The problem being there is a long history of utopia's that despite their provocations end up being philosophical thought experiments overly distant from more practical measures (Garforth 2018). Terry Eagleton (1991:131) argues for a more progressive utopian sensibility that seeks 'somehow to anchor what is desirable to what is actual'. This would move utopia from simply being a form of wishful thinking to an active engagement with the present. Rebecca Solnit (2004:15) argues all democratic struggles require a sense of hopefulness as this is always confronted by a sense of despair that suggests such struggles are not really worth it. Indeed many contemporary environmental writers often sound Marcusian in this respect. There are signs within some of the popular environmental literature of an enhanced questioning of what might be termed a purely instrumental disposition to climate change. Charles Eisenstein (2018) explicitly seeks to problematise a calculative attitude towards carbon emissions for one that seeks to develop a more complex disposition grounded in love and human connection. Similarly the artist Paul Kingsnorth (2017) is sceptical of an environmentalism that quickly because disconnected from local attachments and orientated around the global calculus of carbon emissions. Like Herbert Marcuse, these arguments can be located within a Romantic critique of capitalism based on the rejection of instrumentalism, commodification and the reification of social life (Lowy 1999). The re-enchantment of the commons depends on the recovery of new languages and attachments to nature. Silvia Federici (2019) similarly argues that a deeper more spiritual attachment to nature and a partial turning away from the seductions of technology and a life lived inside will all be necessary work in attempts to reimagine this connection.

The development of more utopian sensibilities amongst the young suggests that another world and future might be possible. The neoliberal attempt to persuade young people to be 'positive' about the existing state of the world is failing (Davies 2016). If Marcuse argued that the demand to be happy was a radical demand in the 1960s this has now been progressively commodified. Of course Marcuse would not have been surprised about how the demands of the radical movements of the 1960s for a less repressed and more fufilled life has been progressively incorporated by capitalism and gurus of positive psychology. However questions of well-being and happiness could yet return as a radical demand through a politics that rejects economic growth at all costs and citizens that seek to explore less damaging forms of prosperity beyond the market (Kalllis 2018). There is now a growing literature 
thinking less about 'smart' ways of reducing our carbon foot print but how we might be able to live more simple, equal and more communally focused lives. Unhooking ourselves from the growth model of capitalism is becoming a relatively mainstream discussion if it is not always connected to the kinds of radical socialism to which Marcuse was committed (Jackson 2017, Soper 2020).

More critically the radical sensibilities of the present are more ethical and less concerned with denied pleasure than those identified by Marcuse in the 1960s, but they are similarly concerned about the naked violence being exerted in the name of 'progress'. These demands are deeply concerned with the well-being of other humans, future generations and other species and to some extent offer an on-going alternative to the on-going demand for competition at all costs. Some of Marcuse's concerns are not far from the surface. In one of Marcuse's (2017b, 2017c) final lectures he continues to assert the importance of a cultural and not only material revolution. This would be for a collective sensibility where the beautiful evident in nature had become liberated from the instrumentality of capitalism. This would only be possible in a socialist society where the life instincts have come to the fore. He was well aware that such sentiments were likely to be rejected as overly utopian, but the possibility of a less destructive society was dependent on a new revolutionary politics unlike that which took place in 1917. This revoltion would depend on the full expression of Eros and the human imagination.

Such views bring Marcuse away from more mainstream Marxism to a closer relationship with anarchism. Chaia Heller (1999) suggests that a society built on hierarchy and consumerism requires a new politics built on 'beauty, pleasure, and collectivity as well as access to food, land, and control of the means of production' (Heller 1999:7). Especially important in this would be the release of the 'eco-erotic' allowing human-beings greater freedom to explore their connections and ties with one another, nature and animals (Heller 1999:125). Within this a revolutionary movement would need act as a pedagogic force shifting people away from heirarchichal and centralised systems that crush peoples independence and creativity. Heller suggests that such a movement would need to give expression to a feminist eros where people relearn and explore more pleasurable, relational and creative pusuits beyond beyond capitalism. Much social theory in this respect has been afraid to explore passion and the erotic entanglements of everday life that are necessary to discover the necessary self-love and care that can be an important source of social change. In this regard, 
Marcuse (2017c) towards then end of his life broke with the need for the mass party so beloved by many of his fellow Marxists. He advocated both political education and the need to break away from the 'pseudo democratic process' (Marcuse 2017c:125). Too quckly he reasoned that party structures become places of greed, ambition and corruption instead what was required was smaller more flexible groups. The liberation of the senses during the current period was then less dependent upon heiarchcal forms of leadership than the kinds of open exploration and erotic connection that emerged out of his dialogue with Erich Fromm.

Currently the global capitalist class both refuses to invest in a sustainable future and increasingly seeks to make its money in short term financial speculation (Foster and Magdoff 2009). The transfer of resources necessary to address climate change and growing levels of inequality only becomes possible in the context of concerted pressure from below. As the legacy of Herbert Marcuse (2017b:188) continues to remind us radical politics should offer a radically different way of life and encourage us to explore a 'revolt against imposed needs and pleasures, revolt against misery and insanity of the affluent society'. This radical vision is necessary in the context of a global system and consumer society built upon inequality, poverty, exploitation and ecological devastation which prefers to sacrifice autonomy and creativity to the conformity induced by the market (De Vogli 2013). Despite the need to invest in green energy through the 'green new deal' thereby creating new forms of employment and addressing some of the consequences of neoliberalism this view continues to treat the crisis of nature as an external problem to be solved (Pollin 2018). Following Marcuse the radical politics of the future is more about the centrality of ethical connection between human and non-human natures and the ability of these arguments to create both alternative human sensibilities, solidarities and forms of flourishing. Crucial to this endeavor is a need for the dialectical understanding of systems of domination that both continue to exploit and dominate human and non-human nature while seeking to distract the population from a wider sense of crisis whose own commitment to democracy makes possible the 'Great Refusal' of the future (Marcuse 1964: 63). Marcuse continually argued that this is only made possible by the radical recovery of the role of the imagination. The enhanced critique of 'progress' has already begun in the global environmental movement often expressed as as 'a revolt of the life-instincts against the socially 
organized death instinct' requiring resistance to what currently passes for rationality (Marcuse 2019a:47).

\section{References}

Adams, W. (1991) 'Aesthetics: Liberating the Sense', in Carver, T. (ed) The Cambridge Companion to Marx, Cambridge, Cambridge University Press pp246-274. Angus, I. (2015) 'When Did the Anthropocene Begin... and Why Does it Matter', Monthly Review 67(4) pp1-11.

Angus, I. (2016) Facing the Anthropocene, New York, Montly Review Press.

Bell, D. (2011) 'Does anthropogenic climate change violate human rights?', Critical Review of International Social and Political Philosophy pp99-124.

Benjamin, J. (1990) The Bonds of Love, London, Virago.

Boal, I et al (2005) Afflicted Powers, London, Verso.

Bookchin, M. (2004) Post-Scarcity Anarchism, Oakland, AK Press.

Bonneuil, C. and Fressoz, J.B. (2016) The Shock of the Anthropocene, London, Verso.

Castro, J.S. (2018) Eros and Revolution, Chicago, Haymarket Books.

Clarke, N. (2014) 'Geo-politics and the disaster of the Anthropocene', The

Sociological Review 62, pp19-37.

Danowski, D. and De Castro, E.V. (2017) The Ends of the World, Cambridge, Polity Press.

Davies, W. (2016) The Happiness Industry, London, Verso. 
De Vogli, R. (2013) Progress or Collapse, London, Routledge.

Eagleton, T. (1991) Ideology; an introduction, London, Verso.

Eagleton, T. (2016) Materialism, New Haven and London, Yale University Press.

Eisenstein, C. (2018) Climate: A New Story, Berkeley, North Atlantic Books.

Feenburg, A. (2005) Heidegger and Marcuse: The Catastrophe and Redemption of History, London, Routledge.

Federicic, S. (2019)

Foster, J.B. (2000) Marx's Ecology: Materialism and Nature, New York, Monthly Review Press.

Foster, J.B. (2016) 'Marxism in the Anthropocene: Dialectical Rifts on the Left', International Critical Thought 6(3) pp393-421.

Foster, J.B. and Magdoff (2009) The Great Financial Crisis, New York, Monthly Review Press.

Fromm, E. (1971) The Crisis of Psychoanalysis, London, Penguin.

Fromm, E. (1976) To Have or To Be?, London, Bloomsbury.

Fromm, E. (1971) The Crisis of Psychoanlysis, London, Penguin Books.

Fromm, E. (1976) To Have or To Be?, London, Bloomsbury.

Fromm, E. (1982) Greatness and Limitations of Freud's Theory, London, Abacus.

Fromm, E. (1992) The Art of Being, London, Constable.

Fromm, E.(1993) The Art of Being, Constable, London.

Fromm, E. (1994) 'The Humanist Credo', in Funk, R. (ed) The Erich Fromm Reader, New Jersey, Humanities Press pp127-132.

Garforth, L. (2018) Green Utopias, Cambridge, Polity Press.

Gorz, A. (1982) Farewell to the Working Class: An Essay in Post-Industrial Socialism, London, Pluto Press.

Heller, C. (1999) Ecology of Everyday Life, New York, Black Books.

Illich, I. (1973) Celebration of Awareness, London, Penguin Books.

Jackson, T. (2017) Prosperity Without Growth, London, Routledge.

Jay, M. (2020) Splinter in your Eye, London, Verso.

Kallis, G. (2018) degrowth, Newcastle Upon Tyne, Agenda Publishing.

Kellner, D. (1984) Herbert Marcuse and the Crisis of Marxism, Berkeley, University of California Press.

Kelly, P. (1984) Fighting for Hope, London, Chatto and Windis.

Kelly, P. (1994) Thinking Green!, Berkely, Parallax Press. 
Kingsnorth, P. (2017) Confessions of a Recovering Environmentalist, London, Faber and Faber.

Klein, N. (2017) No Is Not Enough, London, Allen Lane.

Kovel, J. (2002) The Enemy of Nature, London, Zed Books.

Kovel, J. (2008) 'Ecosocialism, Global Justice and Climate Change', Capitalism, Global Justice, and Climate Change 19(2) pp4-14.

Lasch, C. (1980) The Culture of Narcissism, London, Abacus.

Latouche, S. (2015) Farewell to Growth, Cambridge, Polity Press.

Latour, B. (1993) We Have Never Been Modern, Cambridge, Harvard University

Press.

Lowy, M. (1999) 'Under the Star of Romanticism': Walter Benjamin and Herbert Marcuse', in Bleechman, M. (ed) Revolutionary Romanticism, San Francisco, City Lights Books pp197-214.

Luke, T. (1999) Capitalism, Democracy and Ecology: Departing from Marx, Urbana and Chicago, University of Illinois Press.

Malm, A. (2016) Fossil Capitalism, London, Verso.

Malm, A. (2018) The Progress of this Storm, London, Verso.

Malm, A. and Hornborg, A. (2014) 'The geology of mankind? A critique of the Anthropocene narrative', The Anthropocene Review 1(1) pp62-69.

Marcuse, H. (1956) Eros and Civilisation, London, Ark.

Marcuse, H. (1960) Reason and Revolution, Boston, Beacon Press.

Marcuse, H. (1964) One Dimensional Man, London, Sphere Books.

Marcuse, H. (1967) Reason and Revolution, London, Routledge and Kegan Paul

Marcuse, H. (1968a) 'The Concept of Essence', Negations; Essays in Critical Theory, London, Allen Lane pp43-87.

Marcuse, H. (1968b) 'Philosophy and Critical Theory', Negations; Essays in Critical Theory, London, Allen Lane pp134-158.

Marcuse, H. (1968c) ‘Agressiveness in Advanced Industrial Society’, Negations;

Essays in Critical Theory, London, Allen Lane pp248-268.

Marcuse, H. (1969) An Essay on Liberation, Boston, Beacon Press.

Marcuse, H. (1972a) A Study on Authority, London, Verso.

Marcuse, H. (1972b) Counter Revolution and Revolt, London, Allen Lane.

Marcuse, H. (1978) The Aesthetic Dimension, London, MacMillan Press.

Marcuse, H. (1987) Eros and Civilisation, London, Ark. 
Marcuse, H. (1979) 'The Reification of the Proletariat', Canadian Journal of Political and Social Theory 3(1) pp20-23.

Marcuse, H. (2001a) 'Beyond One Dimensional Man', in (ed) Kellner, D. Towards a Critical Theory of Society, London, Routledge pp107-120.

Marcuse, H. (2001b) 'Cultural Revolution', in (ed) Kellner, D. Towards a Critical Theory of Society, London, Routledge pp123-162.

Marcuse, H. (2017a) 'Marxism and the New Humanity: An Unfinished Revolution', in (ed) Kellner, D. The New Left and the 1960s, London, Routledge pp340-345.

Marcuse, H. (2017b) 'The Failure of the New Left', in (ed) Kellner, D. The New Left and the 1960s, London, Routledge pp183-191.

Marcuse, H. (2017c) 'On the New Left', in (ed) Kellner, D. The New Left and the 1960s, London, Routledge pp122-127.

Marcuse, H. (2019a) 'Children of Promethus: 25 Theses on Technology and Society', in (ed) Surak, S. Jansen, P.E. and Reiz, C. (eds) Ecology Critique of Society Today, Santa Barbera, International Herbert Marcuse Society pp43-50.

Marcuse, H. (2019b) 'Ecology and the Critique of Modern Society', in (ed) Surak, S. Jansen, P.E. and Reiz, C. (eds) Ecology Critique of Society Today, Santa Barbera, International Herbert Marcuse Society pp7-20.

Marcuse, H. (2019c) 'Nature and Revolution', in (ed) Surak, S. Jansen, P.E. and Reiz, C. (eds) Ecology Critique of Society Today, Santa Barbera, International Herbert Marcuse Society pp 21-42.

Marx, K. (1992) 'Economic and Philosophical Manuscripts (1844)', in Colletti, L. (ed) Early Writings, London, Penguin pp259-278.

Merchant, C. (1996) Radical Ecology, London, Routledge.

Moore, J.W. (2015) Capitalism in the Web of Life, London, Verso.

Pollin, R. (2018) 'De-Growth vs A New Green Deal', New Left Review 112 pp5-25.

Pleyers, G. (2010) Alter-Globalisation, Cambridge, Polity Press.

Purser, R.E. (2019) McMindfulness, London, Repeater.

Sachs, W. (2017) 'The Sustainable Development Goals and Laudato si: varieties of Post-Development', Third World Quarterly 38(12) 2573-2587.

Saito, K. (2017) Karl Marx’s Ecosocialism, New York, Monthly Review Press.

Smith, N. (1984/2008) Uneven Development, Athens and London, University of Georgia.

Solnit, R. (2004) Hope in the Dark, Edinburgh, Canongate Books. 
Soper, K. (1995) What is Nature? Oxford, Blackwell.

Soper, K. (1996) 'Greening Prometheus; Marxism and Ecology', in Benton, T. (ed) The Greening of Marxism, London, The Guilford Press pp81-99.

Soper, K. (2010) 'Unnatural times? The social imaginary and the future of nature', Sociological Review pp222-235.

Soper, K. (2020) Post-Growth Living, London, Verso.

Stevenson, N. (2017) Human Rights and the Reinvention of Freedom, London, Routledge.

Streeck, W. (2016) How Will Capitalism End? London, Verso.

Vogel, S. (2015) Thinking Like a Mall, MIT Press.

Wolin, R. (2001) Heidegger's Children, Princeton, Princeton University.

Williams, R. (1980) Culture and Materialism, London, Verso. 